\title{
Electrical conductivity test in Piptadenia moniliformis Benth. seeds ${ }^{1}$
}

\author{
Kleane Targino Oliveira Pereira², Gutierres Silva Medeiros Aquino², \\ Tatianne Raianne Costa Alves², Clarisse Pereira Benedito ${ }^{2 *}$, Salvador Barros Torres ${ }^{2}$
}

\begin{abstract}
The electrical conductivity test is a quick, practical and objective test force; however, its effectiveness varies according to the species, quantity of seed, water volumes, soaking temperature, among other factors. The objective of this study was to evaluate the physiological quality of $P$. moniliformis seeds lots by means of the electrical conductivity test, testing different methodologies. For this, two lots were tested in three quantities of time (25, 50 and 75 seeds) and nine soaking times $(2,4,6,12,24,36,48,60$ and 72 hours $)$ in three volumes of water $(50,75$ and $100 \mathrm{~mL})$ at $25^{\circ} \mathrm{C}$. To evaluate the initial quality of the lots, germination percentage, germination speed index, average time of germination, length and dry mass of seedlings were determined. The use of the electrical conductivity test of $P$. moniliformis seeds is recommended using 75 seeds in $75 \mathrm{~mL}$ of water for 2 hours at $25^{\circ} \mathrm{C}$ or seeds in $50 \mathrm{~mL}$ distilled water with 50 seeds per 6 hours at $25^{\circ} \mathrm{C}$.
\end{abstract}

Index terms: catanduva, forest seeds, caatinga biome, vigor.

\section{Teste de condutividade elétrica em sementes de Piptadenia moniliformis Benth.}

RESUMO - O teste de condutividade elétrica é considerado rápido, prático e objetivo na diferenciação de lotes de sementes, no entanto, alguns fatores podem influenciar nos resultados. O objetivo deste trabalho foi avaliar a qualidade fisiológica de lotes de sementes de P. moniliformis por meio do teste de condutividade elétrica. Para isto, foram testados dois lotes em três quantidades de sementes ( 25,50 e 75 sementes) e nove tempos de embebição $(2,4,6,12,24,36,48,60$ e 72 horas) em três volumes de água $(50,75$ e $100 \mathrm{~mL})$ a $25^{\circ} \mathrm{C}$. Para avaliação da qualidade inicial dos lotes determinou-se a porcentagem de germinação, índice de velocidade de germinação, tempo médio de germinação, comprimento e massa seca de plântulas. Adotou-se o delineamento inteiramente casualizado, em esquema fatorial 2x3x9 (2 lotes, 3 quantidade de sementes, 9 períodos de embebição) avaliados para cada volume separadamente, realizando-se a comparação entre médias pelo teste Tukey a 5\% de probabilidade. De acordo com os resultados, recomenda-se o uso do teste de condutividade elétrica em sementes de $P$. moniliformis utilizando $50 \mathrm{~mL}$ de água destilada com 50 sementes por 6 horas ou com 75 sementes em $75 \mathrm{~mL}$ de água durante 2 horas, a $25^{\circ} \mathrm{C}$.

Termos para indexação: catanduva, sementes florestais, bioma caatinga, vigor.

\section{Introduction}

Piptadenia moniliformis Benth. belongs to the Fabaceae family, popularly known, in Brazilian Portuguese, as catanduva, angico-de-bezerro or rama-de-bezerro, whose size ranges from four to nine meters tall and it occurs frequently in the Brazilian Northeast, especially in the states of Maranhão, Piauí and Ceará to Bahia. It is a pioneer, rustic, and fast growing species, suitable for heterogeneous reforestation with preservationists purposes. Because of its wood being heavy, it is employed in small construction projects, light carpentry, tools handles and for firewood and charcoal. Generally, it annually produces an abundant amount of viable seeds (Maia, 2004).

The use of good quality seeds is a key factor for obtaining quality seedlings and successful forestry enterprises, and the main attribute to consider is the germination capacity, routinely measured in laboratories (Gonçalves et al., 2008).

This method, however, can provide results which overstate the seeds physiological potential due to being conducted at optimum temperature, substrate and light conditions. Thus, existing vigor tests seek to complement the results obtained in the germination test, since they provide more precise indexes in relation to the seeds physiological potential, increasing safety in the lots differentiation (Ohlson et al., 2010).

${ }^{1}$ Submitted on $7 / 22 / 2015$. Accepted for publication on $10 / 1 / 2015$.

${ }^{2}$ Departamento de Ciências Vegetais, Universidade Federal Rural do Semi-Árido, Caixa Postal 137, 59625-900 - Mossoró, RN, Brasil.

*Corresponding author $<$ clarisse@ufersa.edu.br $>$ 
Among the vigor tests, the electrical conductivity test is considered one of the most indicated by International Seed Testing Association (ISTA, 1995) and by the Association of Official Seed Analysts (AOSA, 2009) because of its objectivity and speed, plus the ease of execution. The principle of the test establishes that less vigorous (or more deteriorated) seeds have a lower speed for restoring integrity of cell membranes during soaking and therefore release greater amounts of solutes (sugars, amino acids, fatty acids, proteins, enzymes and inorganic ions) to the external environment (Machado et al., 2011; Marcos-Filho, 2015).

The electrical conductivity results can be influenced by various factors such as the amount of seed, volume of the soaking water, moisture content, soaking timing and temperature, genotype, among others. Therefore, the use of an appropriate procedure makes it possible to estimate seed vigor, reducing risks and losses, and assisting in the decision making regarding the lots use or disposal (Anes et al., 2007).

Research on the electrical conductivity test in seeds of some tree species has been carried out, such as in Guazuma ulmifolia (Gonçalves et al., 2008), Dictyloma vandellianum (Flavio and Paula, 2010), Albizia hassleri (Gonzales et al., 2009), Pterogyne nitens (Ataide et al., 2012), Solanum sessiflorum (Pereira and Martins Filho, 2012), Bowdichia virgilioides (Dalanhol et al., 2014), Anadenanthera falcata (Stallbaun et al., 2015).

However, studies related to this test on seeds of native forest species from the Caatinga are still very incipient, especially when it comes to comparing vigor between lots. In this light, besides the forest and ecological importance and the multiple uses of the species concerned, this study has aimed to evaluate the physiological quality of $P$. moniliformis Benth. seeds by means of different procedures in the electrical conductivity test.

\section{Material and Methods}

The experiment was conducted at the Seed Analysis Laboratory, located at the Universidade Federal Rural do Semi-Árido - UFERSA, Mossoró, RN, Brazil. For this, P. moniliformis seeds were collected in ten matrices, with a distance of approximately 100 meters, located in the Brazilian municipalities of Areia Branca, RN (4'56'52' $\mathrm{S}$ and 37 $\left.7^{\circ} 28^{\prime \prime} \mathrm{O}\right)$ and Mossoró, RN $\left(5^{\circ} 2^{\prime} 5160^{\prime \prime} \mathrm{S}\right.$, $37^{\circ} 20^{\prime} 35.79^{\prime \prime} \mathrm{O}$ ), constituting lots I and II, respectively.

After harvest, the fruits were transported to the Seed Testing Laboratory at UFERSA, and the seeds were manually extracted and processed, discarding the shriveled ones, and the ones affected by insects or fungi, packed in plastic bottles and stored in a cold chamber $\left(10{ }^{\circ} \mathrm{C}\right.$ and $50 \%$ relative humidity) until the establishment of the experiments.

Initially, the seed moisture content of each lot was determined by the oven method at $105 \pm 3{ }^{\circ} \mathrm{C}$ for 24 hours (Brasil, 2009), using two replications of 25 seeds. Prior to the germination tests, the seeds were submitted to the pregermination treatment of immersion in hot water for 15 minutes to accelerate the soaking process (Benedito et al., 2008).

Percentage, speed index and mean germination time: carried out in a towel paper roll substrate according to the methodology by Azerêdo et al. (2011), previously sterilized in an oven at $120^{\circ} \mathrm{C}$ for two hours, then moistened with distilled water in an amount equal to 2.5 times the dry substrate mass (Brasil, 2009). Four replications of 25 seeds were used and the test was conducted in a germination chamber at $30^{\circ} \mathrm{C}$ with a photoperiod of 8 hours and 16 hours in the dark. The counts of germinated seeds was performed daily, starting on the fourth day and extending until the tenth day (period in which germination stabilization was seen) after the experiment establishment. The germination speed index was calculated according to Maguire (1962) and the mean germination time determined by Labouriau (1983).

Seedling length: at the end of the germination test, normal seedlings were measured with the aid of a ruler graduated in centimeters from the root end to the apical bud and the results were expressed in centimeters.seedling ${ }^{-1}$.

Seedling dry matter: after measuring the seedlings, they were packaged in kraft paper bags and placed in an oven with forced air circulation at $65^{\circ} \mathrm{C}$ for 48 hours, when it obtained a constant weight, and then they were weighed on an analytical balance $(0.001 \mathrm{~g})$, and the results were expressed as grams.seedling ${ }^{-1}$.

Electrical conductivity test: combinations were used, resulting from the use of different soaking times $(2,4,6,12,24$, $36,48,60$ and 72 hours), number of seeds per repetition $(25,50$ and 75$)$, and amounts of distilled water $(50,75$ and $100 \mathrm{~mL})$ for soaking the seeds in plastic cups $(150 \mathrm{~mL})$ containing distilled water and stored at $25{ }^{\circ} \mathrm{C}$. After the conditioning period, the solution electrical conductivity was determined by readings in a Digimed DM-31 conductivity meter, and the mean values were obtained for each lot, expressed in $\mu \mathrm{S} . \mathrm{cm}^{-1} \cdot \mathrm{g}^{-1}$ of seeds.

The experimental design used was a completely randomized one, with four replications. Data from the electrical conductivity test were analyzed in a $2 \times 3 \times 9$ factorial design (2 lots, 3 amounts of seeds, 9 soaking times) separately evaluated for each volume $(50,75$ and $100 \mathrm{~mL})$, performing the comparison among means by Tukey's test at 5\% probability, using the statistical analysis software Sisvar (Ferreira, 2011). To assess the progress in the electrical conductivity values with increasing soak time, polynomial regression was studied 
with the same software mentioned above.

\section{Results and Discussion}

The seeds water content values (Table 1) demonstrate that these seed lots have a similar moisture pattern with lower values than the lots differentiation maximum amplitude by the water content, which is 1 to 2 percentage points (MarcosFilho, 1999). According to Vieira and Krzyzanowski (1999), this moisture content similarity is of great importance, since it contributes to achieving uniform results and the correct interpretation of the lots physiological quality.

Table 1. Water content (WC), germination (G), germination speed index (GSI), mean germination time (MGT), seedling length (SL) and seedlings dry matter (SDM) of P. moniliformis Benth. seeds.

\begin{tabular}{ccccccc}
\hline Lots & $\begin{array}{c}\text { WC } \\
(\%)\end{array}$ & $\begin{array}{c}\text { G } \\
(\%)\end{array}$ & GSI & $\begin{array}{c}\text { MGT } \\
(\text { days })\end{array}$ & $\begin{array}{c}\text { SL } \\
(\mathrm{cm})\end{array}$ & $\begin{array}{c}\text { SDM } \\
(\mathrm{g})\end{array}$ \\
\hline I & 9.6 & $68 \mathrm{a}$ & $7.35 \mathrm{a}$ & $1.66 \mathrm{a}$ & $7.08 \mathrm{a}$ & $0.02 \mathrm{a}$ \\
II & 9.9 & $79 \mathrm{a}$ & $9.67 \mathrm{a}$ & $1.80 \mathrm{a}$ & $7.09 \mathrm{a}$ & $0.02 \mathrm{a}$ \\
\hline CV $(\%)$ & & 13.83 & 16.12 & 16.86 & 4.48 & 0.0 \\
\hline
\end{tabular}

There was no statistical difference between the seeds of lots I and II in any of the variables analyzed for initial quality (Table 1). However, high scores and similarities in the germination test do not necessarily mean that the two lots have high vigor, since the test is conducted in controlled conditions of temperature, substrate and moisture, contributing to the ultimate expression of germination vigor. In addition, germination is the last characteristic affected by seeds deterioration process; therefore, it often does not detect any difference in vigor between lots (Marcos-Filho, 2015).

Similar results to this study were found by Pinho et al. (2009), where the germination test has not shown to be sensitive in ordering the lots in the evaluation of the physiological quality of Anadenanthera peregrina seeds. Also, significant differences in germination between four lots of cocona seeds (Solanum sessiliflorum) were not detected. As for the species jacarandá-da-bahia (Dalbergia nigra; commonly known as the Bahia rosewood, Brazilian rosewood, Rio rosewood, jacarandá do Brasil, pianowood, caviuna, or obuina), the germination test could differentiate lots into vigor levels (Marques et al., 2002).

In general, it is clear that the various water volume combinations (50, 75 and $100 \mathrm{~mL}$ ) and quantity of seeds (25, 50 and 75) were able to sort the lots at different levels of vigor, varying only the time of soaking. For the amount of leached released, it was found that lot I was more vigorous than lot II in all combinations, as it showed lower values of electrical conductivity (Table 2). Thus, it appears that the membranes disruption, detected in the electric conductivity test by means of the exudates release, is a natural consequence of all seeds, whose intensity varies according to the species and degree of deterioration (Ataide et al., 2012).

Regardless of the amount of seeds, higher conductivity values were observed in smaller volumes of water, indicating a higher concentration of exudates. Also, a higher concentration of electrolytes in water was observed in the course of the immersion time in all combinations (Table 2, Figures 1, 2 and 3), confirming the results obtained by Dalanhol et al. (2014), which also observed a steady increase of leachates with increasing soaking time and at lower volumes of water for Bowdichia virgilioides Kunth seeds.

For seeds soaked in $50 \mathrm{~mL}$ of water it was possible to observe an increase in the electrical conductivity values as the soaking time increased; however, when using 25 seeds, lots differentiation occurred only at 60 hours of soaking. In contrast, using 50 seeds it was possible to distinguish between lots I and II, starting at 6 hours of soaking, with the ones from lot II presented the largest quantities of exudates released in water, thereby with lower quality (Table 2, Figure 1B). These results agree in part with the results obtained by Ataide et al. (2012) in Pterogyne nitens Tull. seeds, which recommended the use of 50 seeds in $50 \mathrm{~mL}$ of distilled water, but for 24 hours to distinguish lots in vigor level.

Dutra et al. (2007), in conducting the electrical conductivity test in seeds of Senna siamea (Lam.) H.S. Irwin $\&$ Barneby, were able to obtain stratification of the lots when using 50 seeds in $75 \mathrm{~mL}$ of deionized water at $30^{\circ} \mathrm{C}$ for 6 hours of soaking. In Jatropha curcas seeds, Araujo et al. (2011) recommended the period of 6 hours with 15 seeds and $75 \mathrm{~mL}$ to evaluate these seeds physiological quality. Moreover, with 75 seeds the distinction between lots occurred only with 24 hours of soaking.

Looking at the volume of $75 \mathrm{~mL}$ with 25 seeds, it was found that it was only possible to stratify the lots after 12 hours of soaking (Table 2, Figure 2A), but with 50 seeds, the distinction was only possible after 36 hours (Table 2, Figure 2B). However, when the number was increased to 75 seeds in the same volume of water, the differentiation between lots occurred as early as two hours of soaking, the seeds of lot I standing out as vigorous, showing conductivity values significantly lower than in lot II (Table 2, Figure 2C). 
Table 2. Electrical conductivity of mass $\left(\mu \mathrm{S} . \mathrm{cm}^{-1} \cdot \mathrm{g}^{-1}\right)$ of Piptadenia moniliformis Benth. seeds in samples of 25, 50 and 75 seeds, packed in 50,75 and $100 \mathrm{~mL}$ of distilled water for different soaking times at $25^{\circ} \mathrm{C}$.

\begin{tabular}{|c|c|c|c|c|c|c|}
\hline \multirow{2}{*}{ Soaking time } & \multicolumn{2}{|c|}{25 seeds } & \multicolumn{2}{|c|}{50 seeds } & \multicolumn{2}{|c|}{75 seeds } \\
\hline & Lot I & Lot II & Lot I & Lot II & Lot I & Lot II \\
\hline \multicolumn{7}{|c|}{$50 \mathrm{~mL}$ of water } \\
\hline $2 \mathrm{~h}$ & $65.13 \mathrm{aD}^{*}$ & $65.21 \mathrm{aE}$ & $46.88 \mathrm{aE}$ & $93.90 \mathrm{aF}$ & $61.96 \mathrm{aE}$ & $124.62 \mathrm{aG}$ \\
\hline $4 \mathrm{~h}$ & $105.37 \mathrm{aCD}$ & $124.67 \mathrm{aDE}$ & $89.78 \mathrm{aDE}$ & $164.82 \mathrm{aF}$ & $105.37 \mathrm{aE}$ & $178.27 \mathrm{aG}$ \\
\hline $6 \mathrm{~h}$ & $140.15 \mathrm{aBCD}$ & $164.92 \mathrm{aCDE}$ & $124.85 \mathrm{bCDE}$ & $232.70 \mathrm{aEF}$ & $158.10 \mathrm{aDE}$ & $261.05 \mathrm{aFG}$ \\
\hline $12 \mathrm{~h}$ & $205.15 \mathrm{aABCD}$ & $218.45 \mathrm{aBCDE}$ & $212.70 \mathrm{bBCD}$ & $354.05 \mathrm{aDE}$ & $273.50 \mathrm{aCD}$ & $371.50 \mathrm{aF}$ \\
\hline $24 \mathrm{~h}$ & $238.12 \mathrm{aABC}$ & $242.97 \mathrm{aBCD}$ & $274.75 \mathrm{bABC}$ & $448.42 \mathrm{aCD}$ & $398.70 \mathrm{bBC}$ & $626.95 \mathrm{aE}$ \\
\hline $36 \mathrm{~h}$ & $254.30 \mathrm{aABC}$ & $302.07 \mathrm{aABC}$ & $342.77 \mathrm{bAB}$ & $545.57 \mathrm{aC}$ & $512.55 \mathrm{bAB}$ & $822.17 \mathrm{aD}$ \\
\hline $48 \mathrm{~h}$ & $277.75 \mathrm{aAB}$ & $345.60 \mathrm{aAB}$ & $374.67 \mathrm{bAB}$ & $720.30 \mathrm{aB}$ & $562.15 \mathrm{bA}$ & $1108.80 \mathrm{aC}$ \\
\hline $60 \mathrm{~h}$ & $292.90 \mathrm{bAB}$ & $407.77 \mathrm{aA}$ & $412.92 \mathrm{bA}$ & $882.00 \mathrm{aAB}$ & $604.60 \mathrm{bA}$ & $1347.75 \mathrm{aB}$ \\
\hline $72 \mathrm{~h}$ & $317.30 \mathrm{bA}$ & $451.27 \mathrm{aA}$ & $428.10 \mathrm{bA}$ & $996.30 \mathrm{aA}$ & $654.72 \mathrm{bA}$ & $1595.75 \mathrm{aA}$ \\
\hline \multicolumn{7}{|c|}{$75 \mathrm{~mL}$ of water } \\
\hline $2 \mathrm{~h}$ & $31.94 \mathrm{aC}$ & $41.12 \mathrm{aE}$ & $39.53 \mathrm{aE}$ & $54.82 \mathrm{aG}$ & $49.01 \mathrm{bE}$ & $158.34 \mathrm{aG}$ \\
\hline $4 \mathrm{~h}$ & $55.80 \mathrm{aBC}$ & $75.71 \mathrm{aDE}$ & $65.16 \mathrm{aDE}$ & $107.83 \mathrm{aFG}$ & 83.79 bDE & $211.15 \mathrm{aFG}$ \\
\hline $6 \mathrm{~h}$ & $75.52 \mathrm{aABC}$ & $109.70 \mathrm{aCDE}$ & $91.57 \mathrm{aDE}$ & $145.10 \mathrm{aEF}$ & $117.30 \mathrm{bDE}$ & $240.85 \mathrm{aFG}$ \\
\hline $12 \mathrm{~h}$ & $106.60 \mathrm{bABC}$ & $159.42 \mathrm{aBCD}$ & $177.95 \mathrm{aCD}$ & $235.45 \mathrm{aDE}$ & 186.02 bCD & $323.17 \mathrm{aEF}$ \\
\hline $24 \mathrm{~h}$ & $135.65 \mathrm{bABC}$ & $184.55 \mathrm{aBCD}$ & $215.45 \mathrm{aBC}$ & $278.87 \mathrm{aCD}$ & $272.37 \mathrm{bBC}$ & $429.75 \mathrm{aDE}$ \\
\hline $36 \mathrm{~h}$ & $138.95 \mathrm{bABC}$ & $213.50 \mathrm{aABC}$ & $271.57 \mathrm{bABC}$ & $353.25 \mathrm{aC}$ & $333.40 \mathrm{bAB}$ & $539.85 \mathrm{aD}$ \\
\hline $48 \mathrm{~h}$ & $152.02 \mathrm{bAB}$ & $244.20 \mathrm{aAB}$ & $306.75 \mathrm{bAB}$ & $497.02 \mathrm{aB}$ & $362.47 \mathrm{bAB}$ & $731.22 \mathrm{aC}$ \\
\hline $60 \mathrm{~h}$ & $161.47 \mathrm{bAB}$ & $273.67 \mathrm{aAB}$ & $392.02 \mathrm{bAB}$ & $609.77 \mathrm{aAB}$ & $387.52 \mathrm{bAB}$ & $958.35 \mathrm{aB}$ \\
\hline $72 \mathrm{~h}$ & $171.95 \mathrm{bA}$ & $311.27 \mathrm{aA}$ & $359.00 \mathrm{bA}$ & $682.85 \mathrm{aA}$ & $431.32 \mathrm{bA}$ & $1075.65 \mathrm{aA}$ \\
\hline \multicolumn{7}{|c|}{$100 \mathrm{~mL}$ of water } \\
\hline $2 \mathrm{~h}$ & $23.7 \mathrm{aD}$ & $26.77 \mathrm{aF}$ & $29.58 \mathrm{aD}$ & $46.03 \mathrm{aE}$ & $34.94 \mathrm{aD}$ & $69.69 \mathrm{aF}$ \\
\hline $4 \mathrm{~h}$ & $37.36 \mathrm{aCD}$ & $47.35 \mathrm{aEF}$ & $47.71 \mathrm{aCD}$ & $66.92 \mathrm{aE}$ & $61.29 \mathrm{aD}$ & $99.34 \mathrm{aF}$ \\
\hline $6 \mathrm{~h}$ & $54.88 \mathrm{aBCD}$ & $68.18 \mathrm{aDEF}$ & $64.25 \mathrm{aCD}$ & $91.16 \mathrm{aDE}$ & $87.47 \mathrm{aCD}$ & $135.15 \mathrm{aF}$ \\
\hline $12 \mathrm{~h}$ & $89.98 \mathrm{aABCD}$ & $102.12 \mathrm{aCDE}$ & $108.40 \mathrm{bBC}$ & $153.32 \mathrm{aD}$ & $148.25 \mathrm{bC}$ & $237.02 \mathrm{aE}$ \\
\hline $24 \mathrm{~h}$ & $107.25 \mathrm{aABC}$ & $122.70 \mathrm{aBCD}$ & $144.27 \mathrm{bAB}$ & $238.87 \mathrm{aC}$ & $223.02 \mathrm{aB}$ & $282.32 \mathrm{aE}$ \\
\hline $36 \mathrm{~h}$ & $114.32 \mathrm{aAB}$ & $132.8 \mathrm{aABCD}$ & $157.30 \mathrm{bAB}$ & $259.10 \mathrm{aC}$ & $256.15 \mathrm{bAB}$ & $354.82 \mathrm{aD}$ \\
\hline $48 \mathrm{~h}$ & $122.03 \mathrm{bAB}$ & $155.20 \mathrm{aABC}$ & $169.80 \mathrm{bAB}$ & $294.50 \mathrm{aBC}$ & $285.27 \mathrm{bAB}$ & $490.47 \mathrm{aC}$ \\
\hline $60 \mathrm{~h}$ & $128.27 \mathrm{bA}$ & $175.05 \mathrm{aAB}$ & $174.35 \mathrm{bAB}$ & $362.20 \mathrm{aAB}$ & $299.45 \mathrm{bA}$ & $590.45 \mathrm{aB}$ \\
\hline $72 \mathrm{~h}$ & $135.85 \mathrm{bA}$ & $198.80 \mathrm{aA}$ & $188.12 \mathrm{bA}$ & $426.72 \mathrm{aA}$ & $326.02 \mathrm{bA}$ & $662.65 \mathrm{aA}$ \\
\hline
\end{tabular}

*For each combination between seeds amount and water volume, means followed by the same lowercase letter in the row (lots) and uppercase letter in the column (soaking time) do not differ statistically by the Tukey's test at $5 \%$ probability.

Likewise, Santos and Paula (2005) have also been able to differentiate lots of Sebastiania commersoniana by means of the electrical conductivity test from two hours of soaking using 75 seeds soaked in 50,75 and $100 \mathrm{~mL}$ of water. Pereira and Martins Filho (2012), when working with cocona (Solanum sessiflorum) seeds, were also able to identify the lot with the highest seed vigor in only two hours of soaking seeds.

It was found that increasing the volume of water of immersion resulted in decrease in conductivity values due to the dilution effect of exudates. This happens more clearly when it is associated with lower quantities of seeds. The volume of $100 \mathrm{~mL}$ using 25 seeds could only separate the lots from 48 hours on (Table 2, Figure 3A). While in quantities of 50 and 75 seeds in this volume the separation of the lots occurred from 12 hours on (Table 2, Figures 3B and
3C). Flavio and Paula (2010) have also found little difference in leaching standards in the initial soaking period in Dictyoloma vandellianum seeds using this volume of water. Thus, even when perceiving statistical differences between lots, the use of this volume of water for further testing is not recommended.

For Santos and Paula (2005), the lower quantity of seeds per repetition in the lot differentiation can cause controversy due to the dilution into larger volumes of water for soaking; also according to the authors, the use of larger quantities of seeds allows better differentiation between lots due mainly to the greater regularity of the results represented by values lower than the coefficient of variation. Ataide et al. (2012) have also observed a reduction in the conductivity values as they increased the volume of water in Pterogyne nitens Tull. seeds. 

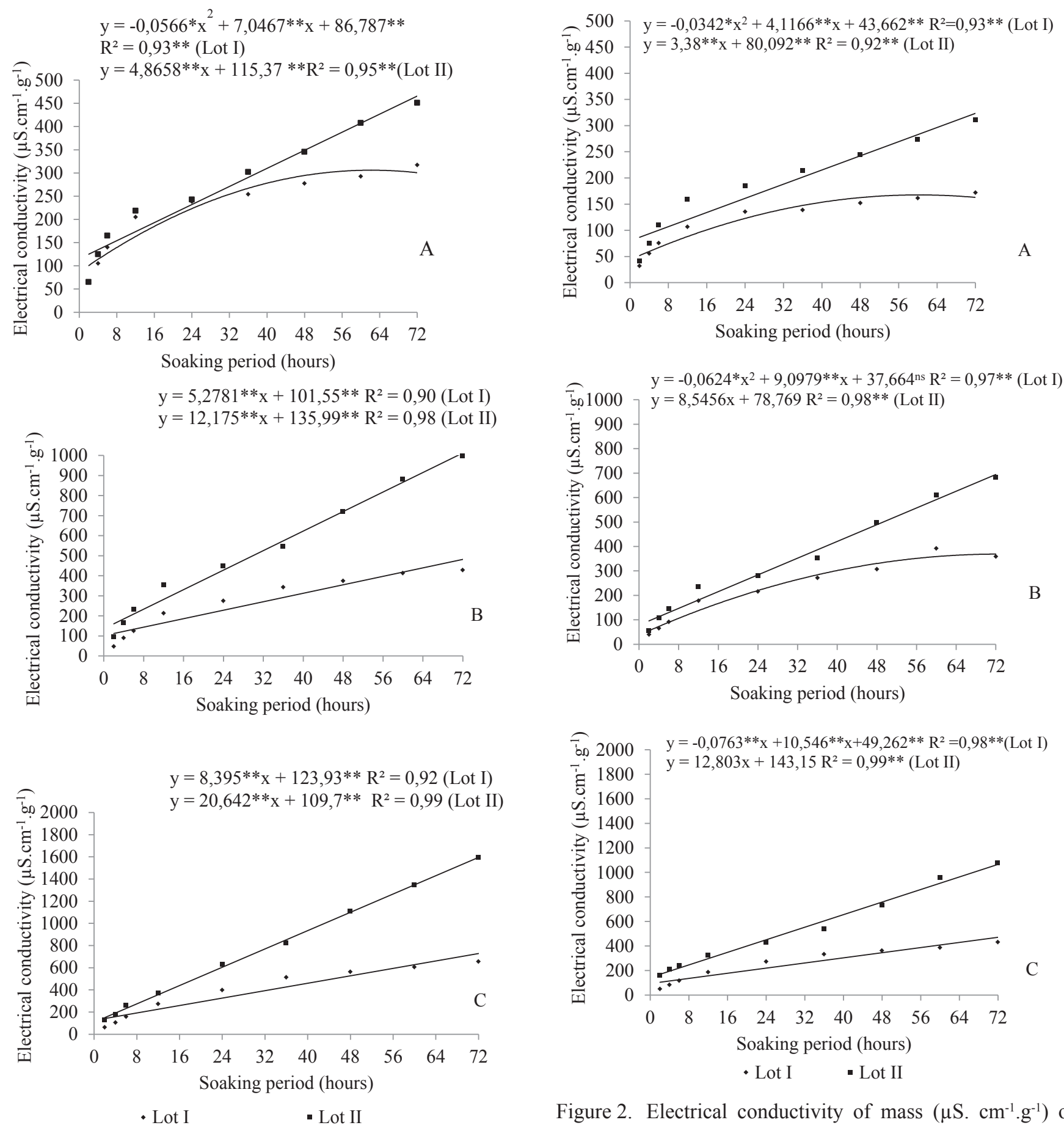

Figure 2. Electrical conductivity of mass $\left(\mu \mathrm{S} . \mathrm{cm}^{-1} \cdot \mathrm{g}^{-1}\right)$ of Piptadenia moniliformis Benth. seeds. Samples with 25 seeds (A), 50 seeds (B) and 75 seeds (C), placed in $75 \mathrm{~mL}$ of distilled water for different soaking times at $25^{\circ} \mathrm{C}$. 

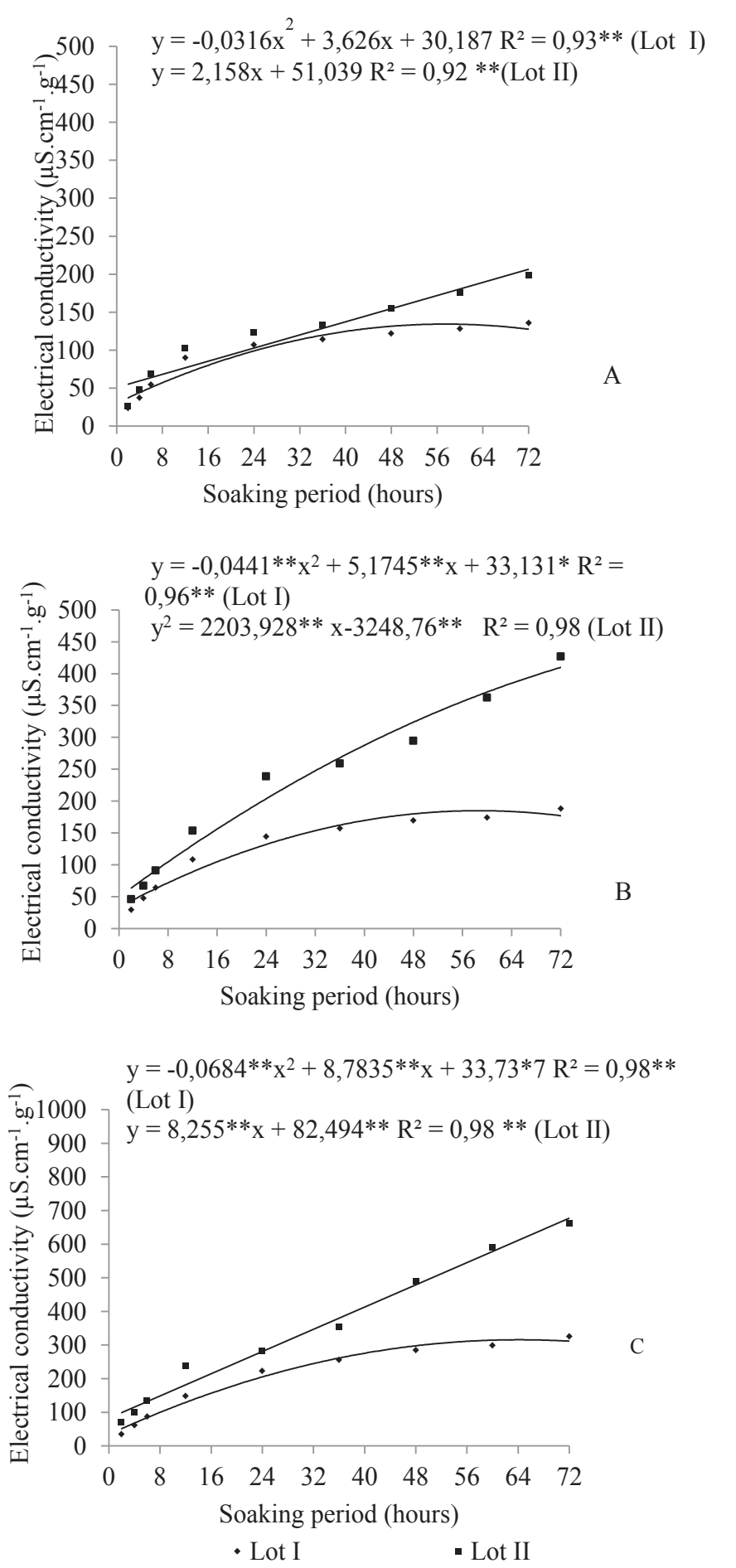

Figure 3. Electrical conductivity of mass $\left(\mu \mathrm{S} . \mathrm{cm}^{-1} \cdot \mathrm{g}^{-1}\right)$ of Piptadenia moniliformis Benth. seeds. Samples with 25 seeds (A), 50 seeds (B) and 75 seeds (C), placed in $100 \mathrm{~mL}$ of distilled water for different soaking times at $25^{\circ} \mathrm{C}$.

Results contrary to the ones obtained in this study were found by Cruz et al. (2013) for Crambe abyssinica Hochst seeds, who found it difficult to differentiate the lots vigor by the electrical conductivity test. In Albizia hassleri seeds, the electrical conductivity test was not suitable for lots discrimination either (Gonzales et al., 2009).

Bonner (1998) states that the electrical conductivity test in forest seeds is unlikely to have a performance similar to that for seeds of major crops, but it is a tool that can help in combination with other tests in differentiating lots for vigor. However, in this work the procedures applied proved to be suitable to the goal established, allowing the differentiation of lots in terms of physiological quality.

Also, according to the results obtained in this study, it was observed that two combinations better differentiated lots, with 50 seeds in $50 \mathrm{~mL}$ of water, allowing the differentiation from 6 hours of soaking on, and the other with 75 seeds in 75 $\mathrm{mL}$ of water, ordering lots starting in two hours.

Despite the species producing large quantities of viable seeds when the weather conditions are favorable, there is still great difficulty in acquiring them, especially in dry seasons, in which production is greatly reduced. Thus, the choice of the most appropriate combination will depend on the seeds availability and production, since there was ordering of the lots in less time (two hours), but using larger amounts of seeds.

\section{Conclusions}

The electrical conductivity test is efficient to distinguish lots of $P$. moniliformis seeds and must be carried out with 75 seeds in $75 \mathrm{~mL}$ of water for 2 hours or 50 seeds in $50 \mathrm{~mL}$ for 6 hours in a constant temperature of $25^{\circ} \mathrm{C}$.

\section{References}

ANES, L.M.M.; COELHO, M.F.B.; ALBUQUERQUE, M.C.F.; MENDONÇA, E.A.F.; DOMBROSKI, J.L.D. Padronização da metodologia do teste de tetrazólio para sementes de Jatropha elliptica M. Arg. (Euphorbiaceae). Revista Brasileira de Plantas Medicinais, v.9, n.3, p.82-88, 2007. http://www.sbpmed.org.br/download/issn_07_3/artigo12_v9_n3.pdf

AOSA. ASSOCIATION OF OFFICIAL SEED ANALYSTS. Seed vigour testing handbook. Ithaca, NY:AOSA, 2009. 341 p. (Contribution, 32).

ARAUJO, R.F.; ZONTA, J.B.; ARAUJO, E.F.; DONZELES, S.M.L.; COSTA, G.M. Teste de condutividade elétrica em sementes de pinhão-manso (Jatropha curcas L.). Idesia, v.29, n.2, p.79-86, 2011. http://www.scielo.cl/ pdf/idesia/v29n2/art10.pdf

ATAIDE, G.M.; FLORES, A.V.; BORGES, E.E.L.; RESENDE, R.T. Adequação da metodologia do teste de condutividade elétrica para sementes de Pterogyne nitens Tull. Revista Brasileira de Ciências Agrárias, v.7, n.4, p.635-640, 2012. $\mathrm{http}: / / \mathrm{www}$.agraria.pro.br/sistema/index.php?journal=agraria\&page=article\&op=view\&path $\% 5 \mathrm{~B} \% 5 \mathrm{D}=$ vi4a1688\&path $\% 5 \mathrm{~B} \% 5 \mathrm{D}=1239$ 
AZERÊDO, G.A.; PAULA, R.C.; VALERI, S.V. Temperatura e substrato para germinação de sementes de Piptadenia moniliformis Benth. Scientia Forestalis, v.39, n.92, p.479-488, 2011. http://www.ipef.br/publicacoes/ scientia/nr92/cap11.pdf

BENEDITO, C.P.; TORRES, S.B.; RIBEIRO, M.C.C.; NUNES, T.A. Superação de dormência de sementes de catanduva (Piptadenia moniliformis Benth.). Revista Ciência Agronômica, v.39, n.1, p.90-93, 2008. http://www.ccarevista.ufc.br/seer/index.php/ccarevista/article/view/29/28 BONNER, F.T. Testing tree seed vigor for loblolly and slash pines. Seed Technology, v.20, n.1, p.5-17, 1998

BRASIL. Ministério da Agricultura, Pecuária e Abastecimento. Regras para análise de sementes. Ministério da Agricultura, Pecuária e Abastecimento. Secretaria de Defesa Agropecuária. Brasília: MAPA/ACS, 2009. 395p. http:// www.agricultura.gov.br/arq_editor/file/2946_regras_analise_sementes.pdf

CRUZ, S.M.; NERY, M.C.; ROCHA, A.S.; VON PINHO, E.V.R.; ANDRADE, P.C.R.; DIAS, D.C.F.S. Vigor tests for evaluation of crambe (Crambe abyssinica Hochst) seed quality. Journal of Seed Science, v.35, n.4, p.485-494, 2013. http://www.scielo.br/scielo.php?script=sci arttext\&pid=S2317-15372013000400010

DALANHOL, S.J.; REZENDE, E.H.; ABREU, D.C.A.; NOGUEIRA, A.C. Teste de condutividade elétrica em sementes de Bowdichia virgilioides Kunth. Floresta e Ambiente, v.21, n.1, p.69-77, 2014. http://www.scielo.br/ $\mathrm{pdf} /$ floram/v21n1/aop floram ao055913.pdf

DUTRA, A.S.; MEDEIROS FILHO, S.; DINIZ, F.O. Teste de condutividade elétrica em sementes de Senna siamea (Lam.) H. S. Irwin \& Barneby. Revista Ciência Agronômica, v.38, n.3, p.280-285, 2007. http://www.ccarevista.ufc. $\mathrm{br} / \mathrm{seer} /$ index.php/ccarevista/article/view/116

FERREIRA, D.F. Sisvar: A computer statistical analysis system. Ciência e Agrotecnologia, v.35, n.6, p.1039-1042, 2011. http://www.scielo.br/scielo. php?pid=S1413-70542011000600001\&script=sci_arttext

FLAVIO, J.J.P.; PAULA, R.C. Testes de envelhecimento acelerado e condutividade elétrica em sementes de Dictyoloma vandellianum A. Juss. Scientia Forestalis, v.38, n.87, p.391-399, 2010. http://www.ipef.br/ publicacoes/scientia/nr87/cap06.pdf

GONÇALVES, E.P.; PAULA, R.C.; DESMATLÊ, M.E.S.P. Testes de vigor em sementes de Guazuma ulmifolia Lam. Semina: Ciências Agrárias, v.29, n.2, p.265-276, 2008. http://www.uel.br/revistas/uel/index.php/semagrarias/ article/view/2812/4937

GONZALES, J.L.S.; PAULA, R.C.; VALERI, S.V. Teste de condutividade elétrica em sementes de Albizia hassleri (Chodat) burkart. Fabaceaemimosoideae. Revista Árvore, v.33, n.4, p.625-634, 2009. http://www.scielo. $\mathrm{br} /$ scielo.php?script $=$ sci arttext\&pid=S0100-67622009000400005

ISTA. INTERNATIONAL SEED TESTING ASSOCIATION. Handbook of vigour test methods. 3 ed. Zurich: ISTA, 1995. $117 \mathrm{p}$.

LABOURIAU, L.G. A germinação das sementes. Washington: Secretaria Geral da Organização dos Estados Americanos, 1983. 174 p.
MACHADO, C.G.; MARTINS, C.C.; SANTANA, D.G.; CRUZ, S.C.S.; OLIVEIRA, S.S.C.Adequação do teste de condutividade elétrica para sementes de Pisum sativum subsp. Ciência Rural, v.41, n.6, p.988-995, 2011. http:// www.scielo.br/scielo.php?script $=$ sci nlinks $\&$ ref $=000067 \&$ pid $=S 0100$ 2945201200020004300012\&lng=pt

MAGUIRE, J.D. Speed of germination aid in selection and evoluation for seedling and vigour. Crop Science, v.2, n.2, p.176-177, 1962.

MAIA, G.N. Caatinga: árvores e arbustos e suas utilidades. São Paulo: D\&Z Computação Gráfica e Editora, 2004. 413 p.

MARCOS-FILHO, J. Teste de envelhecimento acelerado. In: KRZYZANOWSKI, F.C.; VIEIRA, R.D.; FRANÇA-NETO, J.B. (Eds.). Vigor de sementes: conceitos e testes. Londrina: ABRATES, 1999. cap.3, p.1-24.

MARCOS-FILHO, J. Fisiologia de sementes de plantas cultivadas. Londrina: ABRATES, 2015. $660 \mathrm{p}$

MARQUES, M.A.; PAULA, R.C.; RODRIGUES, T.J.D. Adequação do teste de condutividade elétrica para determinar a qualidade fisiológica de sementes de jacarandá-da-bahia (Dalbergia nigra (Vell.) Fr. All. ex Benth. Revista Brasileira de Sementes, v.24, n.1, p.271-278, 2002. http://www.scielo.br/ scielo.php?pid=S0101-31222002000100038\&script=sci arttext

OHLSON, O.C.; KRZYZANOWSKI, F.C.; CAIEIRO, J.T.; PANOBIANCO, M. Teste de envelhecimento acelerado em sementes de trigo. Revista Brasileira de Sementes, v.32, n.4, p.118-124, 2010. http:// www.scielo.br/scielo.php?script $=$ sci_nlinks \& $\mathrm{ref}=000085 \& \mathrm{pid}=\mathrm{S} 0101$ $3122201200040000900017 \& \operatorname{lng}=\mathrm{en}$

PEREIRA, M.D.; MARTINS FILHO, S. Adequação da metodologia do teste de condutividade elétrica para sementes de cubiu (Solanum sessiflorum DUNAL). Revista Agrarian, v.5, n.16, p.93-98, 2012. http://www.periodicos. ufgd.edu.br/index.php/agrarian/article/viewFile/707/1026

PINHO, D.S.; BORGES, E.E.L.; CORTE, V.B.; BHERING, N.L.C. Avaliação da qualidade fisiológica de sementes de Anadenanthera peregrina (L.) Speg. durante o armazenamento. Revista Árvore, v.33, n.1, p.27-33, 2009. http:// www.scielo.br/pdf/rarv/v33n1/v33n1a04

SANTOS, S.R.G.; PAULA, R.C. Teste de condutividade elétrica para avaliação da qualidade fisiológica de sementes de Sebastiania commersoniana (Bail) Smith \& Downs. Revista Brasileira de Sementes, v.27, n.2, p.136-145, 2005. http://www.scielo.br/scielo.php?pid=S0101$31222005000200020 \&$ script $=$ sci arttext

STALLBAUN, P.H.; SOUZA, P.A.; MARTINS, R.C.C.; MATOS, J.M.M.; MOURA, T.M. Testes rápidos de vigor para avaliação da viabilidade de sementes de Anadenanthera falcata. Enciclopédia Biosfera, v.11, n.21, p.1834-1846, 2015. http://www.conhecer.org.br/enciclop/2015b/agrarias/ testes\%20rapidos\%20de\%20vigor.pdf

VIEIRA, R.D.; KRZYZANOWSKI, F.C. Teste de condutividade elétrica. In KRZYZANOWSKI, F.C.; VIEIRA, R.D.; FRANÇA-NETO, J.B. (Eds.). Vigor de sementes: conceitos e testes. Londrina: ABRATES, 1999. cap.4, p.4-9. 